\title{
Dryland tree data for the Southwest region of Madagascar: alpha-level data can support policy decisions for conserving and restoring ecosystems of arid and semiarid regions
}

James C. Aronson',"I, Peter B. Phillipson','II!, Edouard Le Floc'h", Tantely Raminosoalv

\section{ABSTRACT}

We present an eco-geographical dataset of the 355 tree species (156 genera, 55 families) found in the driest coastal portion of the spiny forest-thickets of southwestern Madagascar. This coastal strip harbors one of the richest and most endangered dryland tree floras in the world, both in terms of overall species diversity and of endemism. After describing the biophysical and socio-economic setting of this semiarid coastal region, we discuss this region's diverse and rich tree flora in the context of the recent expansion of the protected area network in Madagascar and the growing engagement and commitment to ecological restoration. Our database, DTsMada (short for Desert Trees of Madagascar), is part of a larger 'work-in-progress', namely an eco-geographical database on desert and dryland trees of the world. DTsMada draws heavily on the Catalogue of the Vascular Plants of Madagascar (MadCat) project, in which floristic, ecological and endemism parameters are compiled, together with available conservation status assessments based on IUCN Red List criteria. Both are projects within the plant systematics database, Tropicos ${ }$, developed at Missouri Botanical Garden and maintained on the Garden's website. To highlight the need for greater study of the interactions between biological, bioclimatic, and anthropogenic determinants of current and potentially changing biogeographical patterns and community dynamics in the tree strata of vegetation in the study area, we consider four contrasting groups of native trees: Adansonia spp. (Malvaceae), Pachypodium spp. (Apocynaceae), Baudouinia spp. (Fabaceae), and all 11 species in the 4 genera of Didiereaceae in Madagascar. We discuss DTsMada as a prototype dataset of alpha level information vital for effective conservation, landscape planning, sustainable use and management, and ecological restoration of degraded arid and semiarid ecosystems, in Madagascar and elsewhere.

\author{
Correspondence: \\ James C. Aronson \\ Missouri Botanical Garden, \\ P.O. Box 299, St. Louis, Missouri 63166-0299, USA \\ Email: ja42014@gmail.com
}

\section{RÉSUMÉ}

Nous présentons un ensemble de données éco-géographiques sur les 355 espèces d'arbres (156 genres, 55 familles) présentes dans les fourrés et forêts épineux de la frange côtière aride et semiaride du Sud-ouest de Madagascar. Cette région possède un des assemblages d'arbres de climat sec les plus riches (en termes de diversité spécifique et d'endémisme), et les plus menacés au monde. Après une description du cadre biophysique et de la situation socio-économique de cette région, nous présentons cette flore régionale dans le contexte de la récente expansion du réseau de des aires protégées de Madagascar et de l'engagement croissant dans le domaine de la restauration écologique. Notre base de données DTSMada (raccourci de « Desert Trees - Madagascar ", en anglais) s'inscrit dans le cadre d'une base de données éco-géographique plus large que nous développons, regroupant les espèces d'arbres des régions arides et semiarides du monde entier, avec un accent particulier mis sur leur utilisation dans la conservation, gestion et restauration écologique. Nombre des informations présentées dans DTsMada proviennent du projet MadCat (Catalogue des plantes vasculaires de Madagascar) qui regroupe des données floristiques et écologiques, et les statuts d'endémisme et de conservation des espèces végétales, basés sur les critères de I'UICN.

Ces deux projets font partie de la base de données taxonomique Tropicos ${ }$, du Jardin Botanique du Missouri. Pour souligner le besoin de disposer de plus d'études pour comprendre : les interactions entre les facteurs biologiques, bioclimatiques et anthropiques qui affectent la biogéographie et les dynamiques des communautés dans les strates arborées de la végétation dans la région étudiée, qu'il s'agisse de la situation actuelle ou celle d'un futur qui sera éventuellement modifié, nous considérons quatre groupes bien différents d'espèces d'arbres in- 


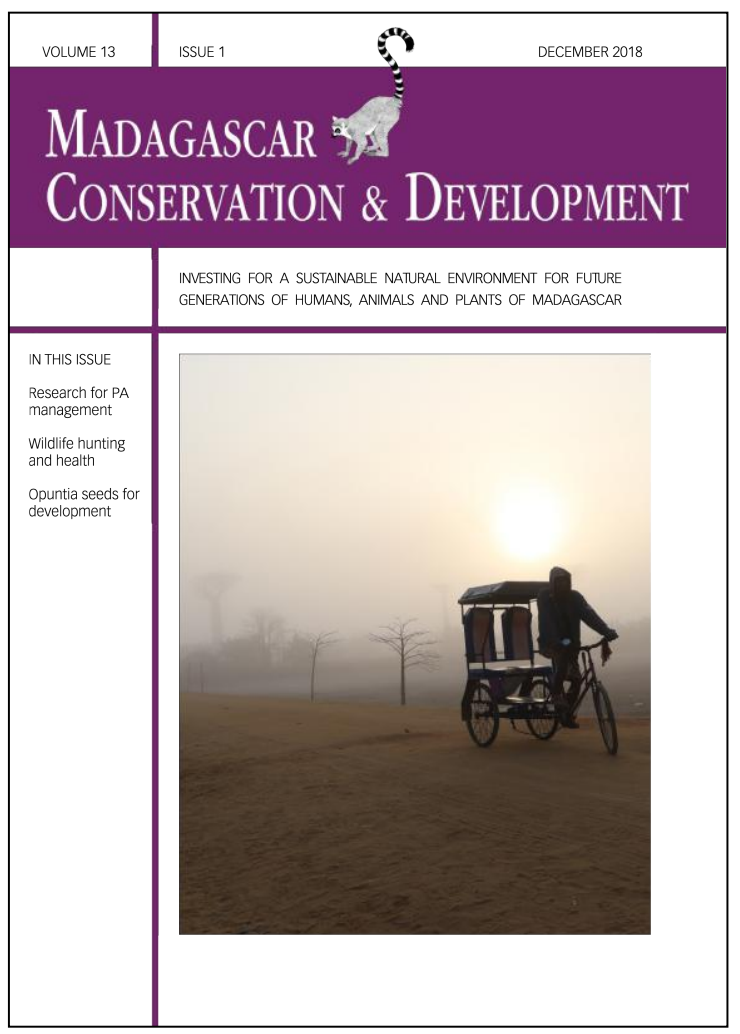

Madagascar Conservation \& Development is the journal of Indian Ocean e-Ink. It is produced under the responsibility of this institution. The views expressed in contributions to MCD are solely those of the authors and not those of the journal editors or the publisher.

All the Issues and articles are freely available at http://www.journalmcd.com

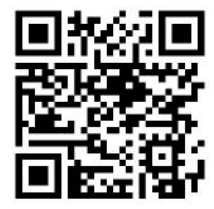

Contact Journal MCD

info@journalmcd.net for general inquiries regarding MCD funding@journalmcd.net to support the journal

Madagascar Conservation \& Development Institute and Museum of Anthropology

University of Zurich

Winterthurerstrasse 190

$\mathrm{CH}-8057$ Zurich

Switzerland

Indian Ocean e-Ink

Promoting African Publishing and Education

www.ioeink.com

Missouri Botanical Garden (MBG)

Madagascar Research and Conservation Program

Missouri Botanical Garden

BP 3391

Antananarivo, 101, Madagascar 
digènes : Adansonia spp. (Malvaceae), Pachypodium spp. (Apocynaceae), Baudouinia spp. (Fabaceae) et les 11 espèces dans les 4 genres de la famille des Didiereaceae du Sud-ouest de Madagascar. Nous traitons DTsMada comme prototype d'une base de données de niveau alpha, vitales pour la conservation, la planification, le développement durable, la gestion et la restauration écologique des écosystèmes arides et semiarides de Madagascar et d'ailleurs.

\section{INTRODUCTION}

Seasonally-dry, inter-tropical forests, woodlands, and thickets are among the most highly threatened and least well-studied terrestrial ecosystems on Earth (Sunderland et al. 2015). They are as rich or richer in both plant and animal species and more productive than other dryland ecosystems and many mesic ones (Aronson et al. 2005), yet their importance-for both biodiversity conservation and delivery of ecosystem services-is often underestimated. The drylands-including the hyperarid, arid, semiarid, and dry-subhumid biomes that occupy $>40 \%$ of the Earth's land surface (Reed and Stringer 2016) -are often treated as if they have little lasting value to people. This in turn tends to lead to a spiral of degradation leading to potentially catastrophic consequences for over two billion people who live in these regions (Reynolds et al. 2007, Lal et al. 2012).

There are two underlying factors that contribute to degradation. Firstly, the unsustainable extraction of woody biomass and palatable fodder through a process called 'artificial negative selection' (Burkhart 1976). The most desirable timber trees are progressively harvested and removed, thus leading to replacement by less desirable individuals of the species, and more generally to species of inferior ecological quality and timber value compared to the ones removed through selective extraction. Similarly, the hardest-wooded trees that people can exploit are generally extracted for charcoal production first-e.g., Baudouinia rouxevillei in southwest Madagascar-while soft-wooded trees (such as Baobabs) are left behind until people have no other choice left but to use them for fiber and wood. Similar patterns of extraction generally apply to forage and fodder consumption, especially when population density is high and people are very poor (Randriamalala et al. 2016). Secondly, the impact of the 'shifting baseline syndrome' proposed by fisheries scientist Pauly (1995), a term coined to describe the gradual lowering of expectations of the quality and quantity of fishery resources with each new generation of people. Although conceived and applied in relation to ocean fish stocks over the past 100 years (Pauly 1995), arguably it applies to dryland ecosystem trees and other valuable resources as well. Many dryland ecosystems and arboreal formations in southwestern Madagascar and elsewhere, were once much more abundant and diverse than they are today (Felger et al. 2001, Le Floc'h and Aronson 2013).

Relative to its size $\left(587,000 \mathrm{~km}^{2}\right)$, Madagascar has a remarkable array of bioclimates which were the subject of an intensive study by Cornet (1974), and vegetation types (Moat and Smith 2007). The island is rich in number of species and in the level of endemism recorded in all groups of organisms. Of the ca.11,400 described species of vascular plants in the country, 95\% are angiosperms, and among these, almost $96 \%$ are indigenous, with only ca. 400 non-native, naturalized species known. Of the indigenous angiosperm flora ca. $84 \%$ have been recorded recently as endemic (Callmander et al. 2011, Rabarimanarivo et al. 2014).
However, every year between 50 and 100 new plant species are described, and it is projected that 2,200 or more species of higher plants endemic to Madagascar remain to be described (Phillipson, unpubl. data), which would bring the total number of described species to more than 13,600 , with vascular plant species endemism for Madagascar close to $90 \%$ (Phillipson 1994, 1996, 2006, Lowry II et al. 1997). Relatively little is known about either historical or contemporary impacts of human land and resource use on the flora and vegetation in Madagascar. In contrast, wild animalplant interactions have received some attention from evolutionary ecologists working on broad time scales (Gautier et al. 2012). For example, Bond and Silander (2007) suggested that various branch and foliage characteristics present in over 20 plant lineages endemic to Madagascar may have evolved as anti-browsing adaptations and for dispersal by elephant birds or aepyornids and other large herbivores now long extinct. Grubb (2003) suggested that the spines covering the stems of most or all Malagasy Didiereaceae, and whose length parallels leaf length, are an evolutionary adaptation to protect the leaves against arboreal primates. They noted that members of the same family in Africa have no spines. More recently, Crowley and Godfrey (2013) found that giant lemurs may have played a key role in the evolution of spines in this group of plants.

The southwestern dry forests and spiny thickets are everywhere highly fragmented due to over-exploitation of wood, bark and fiber by local people, especially for charcoal production, which remains the main source of cooking fuel in Toliara, and other cities throughout the country (Vieilledent et al. 2018). Harper et al. (2007) estimated that at least $28 \%$ of the surface area of forest and spiny thicket was lost between 1950 and 2000, and that in 2000 only 4 million hectares of this vegetation still existed, of which less than half occurred in the coastal area on which we focus in this paper (Figure 1).

Prior to 2003 , less than $3 \%$ of southwestern Madagascar was included in the national network of protected areas. In that year, former President Ravalomanana launched the so-called Durban Vision process to increase the area in Madagascar available for biodiversity management three-fold, from $17,000 \mathrm{~km}^{2}$ to over $60,000 \mathrm{~km}^{2}$ (ca. $10 \%$ of Madagascar's total land area) within 10 years (Virah-Sawmy et al. 2014). The subsequent program to implement the vision process, through the Système d'Aires Protégées de Madagascar (SAPM), has resulted in the formal establishment of 85 additional protected areas by government decrees issued in April and May 2015, as well as significant additions to existing areas. The total number and surface area of the protected area network has been extended to 122 sites covering just over $71,000 \mathrm{~km}^{2}$ (Gardner et al. 2018). Four long-established protected areas in southwestern Madagascar contain areas of dry spiny forest and thicket. These are the Andohahela National Park and the Beza Mahafaly Special Reserve, Tsimanampesotse National Park, the area of which has been recently dramatically increased from $432 \mathrm{~km}^{2}$ to $2,627 \mathrm{~km}^{2}$, and the much smaller $\left(63 \mathrm{~km}^{2}\right)$ Cap Sainte Marie Reserve (Figure 2). In addition, this vegetation type is also represented in certain of the newly established protected areas in the southwest (SAPM 2018) (Figure 2).

The objective of this paper is to present a database of a poorly-studied tree flora that will be part of a worldwide study and an on-line database linked to it, that will cover dryland and desert trees of the world. The global database we are building, and this specific component of it, which we call DTsMada (short for Desert 


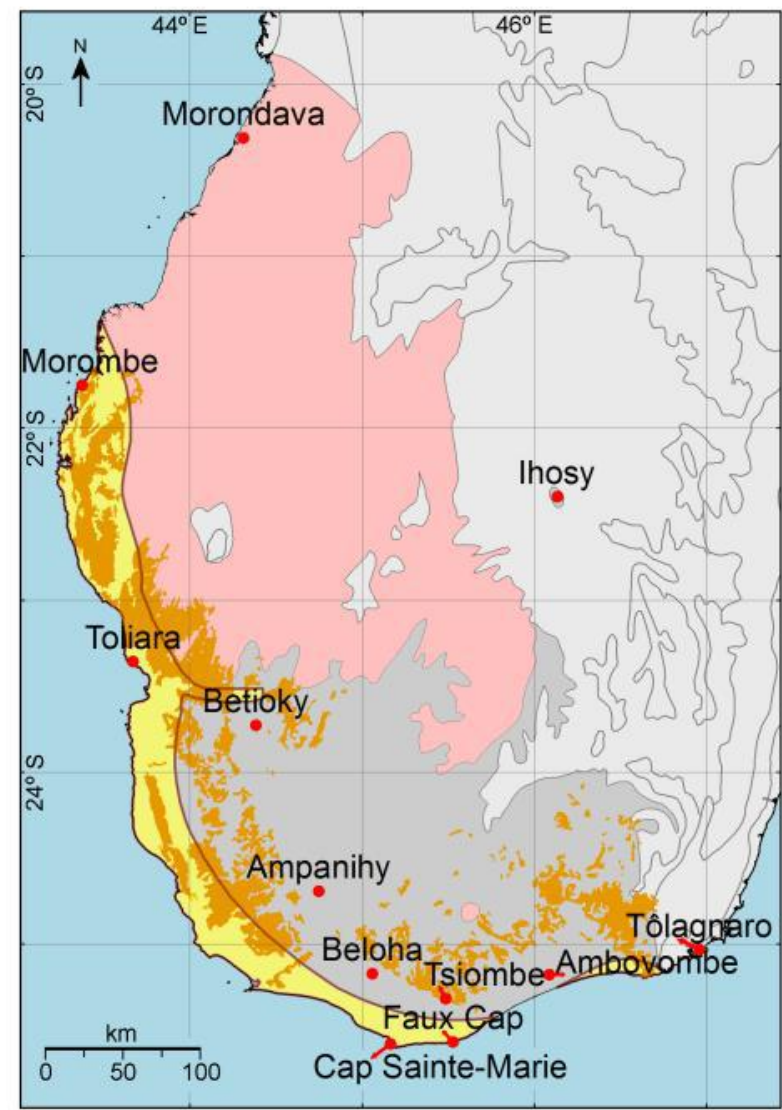

Figure 1. The Semiarid (yellow with brown outline), Lower Subarid (grey), and Upper Subarid (pink) zones in the Dry Southwest region of Madagascar (Cornet 1974). (The scattered areas indicated with orange shading correspond to the ca. 4 million ha of extant spiny forest-thicket in the region (Moat and Smith 2007))

Trees of Madagascar), represent alpha-level information for those engaged in conservation, planning, ecological restoration, and long-term ecosystem management in megadiverse areas not only in Madagascar (Birkinshaw et al. 2013), but also in drylands worldwide. Such databases can provide information in a systematic fashion, and insights, to assist fundamental and applied research, including intentional community reassembly (Verdu et al. 2009, Castillo et al. 2010) through planning for protection and natural regeneration, and active interventions aimed at ecological restoration.

\section{METHODS}

STUDY AREA. Here we consider the tree flora of the coastal

strip of southwestern Madagascar, which is the driest part (mean precipitation 350-450 mm per annum) of the country, with a notably erratic distribution of rainfall, seasonally, annually and spatially (Donque 1975). This area corresponds to the Étage sous aride 3 of Cornet (1994), modified by Schatz (2002) to Subarid 3. Coastal fog contributes additional moisture here (Dewar and Richard 2007), but its role has not been well studied. The formations found here include 'dry spiny forest-thicket', 'degraded dry spiny forest', and 'coastal bushland', as mapped in the Atlas of the vegetation of Madagascar (Moat and Smith 2007). While there are many NGOs and a number of community-based conservation, restoration, and sustainable development projects in Madagascar, especially in the humid, eastern part of the country (Roelens et al 2010, Birkinshaw et al. 2013), far less attention is being paid to the unique and highly threatened ecosystems in the drier regions

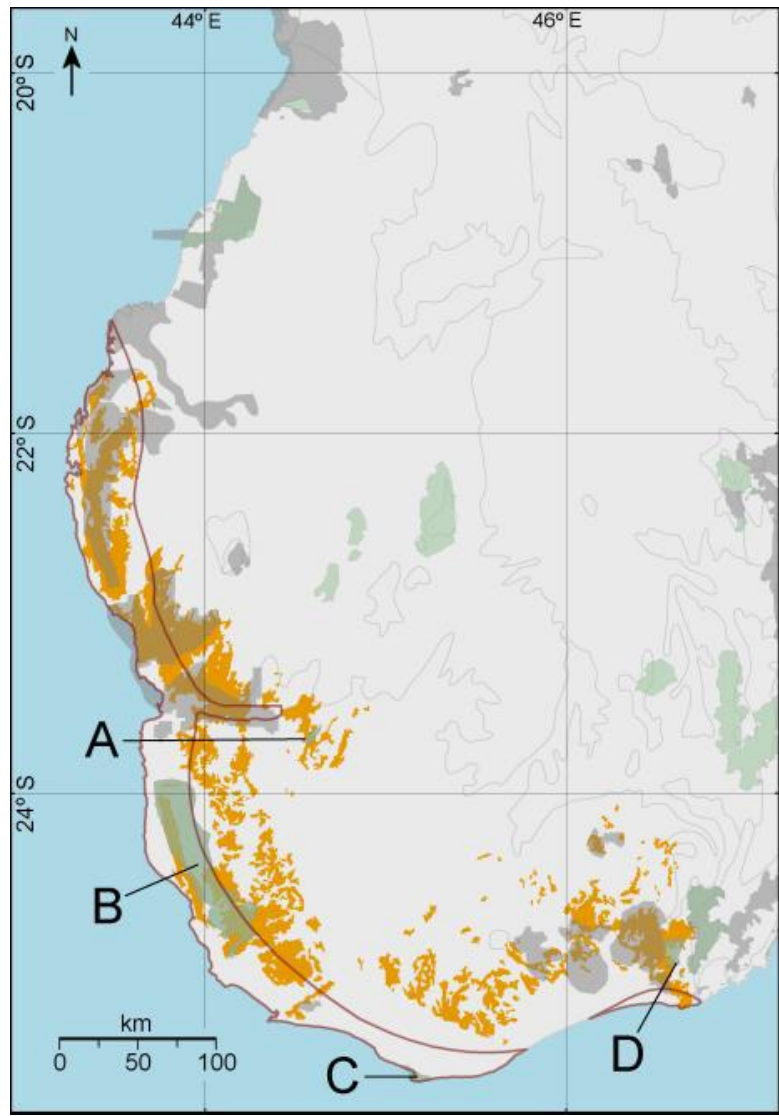

Figure 2. Protected areas in southern Madagascar. (Long-established protected areas in southern Madagascar (shaded green) harboring spiny forest-thicket (shaded orange): A. Bezà-Mahafaly Special Reserve; B. Tsimanampesotse Nationa Park (including recent southeastern extension); C: Cap Sainte Marie Reserve; D. Andohahela National Park (Parcelle II). Newly delimited or proposed protected areas (shaded grey) (Source: SAPM 2018))

(Waeber et al. 2015). This contribution is part of an on-going study and database we are assembling on dryland trees of the world (Le Floc'h and Aronson 2013). We consider the ecology, diversity and distribution, conservation status, horticultural and silvicultural prospects, and the various uses by people of dryland trees to be essential information for all who work for conservation, ecological restoration, and long-term, sustainable ecosystem management in Madagascar, and elsewhere.

The soils of southwestern Madagascar are not diverse, reflecting the relatively simple geology of the region, generally comprising of superficial lithosols and regosols (Cornet 1974). The most conspicuous geological features in the region are the tertiary limestone outcrops that extend from Morombe in the northwest of the region to the extreme south, and which form a series of plateau areas separated by the main river basins draining from the highlands and western slopes of the interior to the southwest coast-namely from south to north the Menarahandra, Linta, Onilahy, Fiherenana, and Mangoky rivers. A generally narrow coastal strip to the west of the limestone outcrops represents a series of ancient, so-called 'aepyornien' dunes (Du Puy and Moat 1996), consisting of consolidated calcareous sandstones derived from the limestone plateau. To the north of Toliara, the Mikea area and at certain sites south of this city, an extensive coastal dune system, varying in width from five to $50 \mathrm{~km}$, overlies the calcareous sandstone formations that reach the surface further inland. In the south, the Karimbola plateau with its calcareous lithosols abuts the rugged basaltic territory of the Androy people, which is adja- 
cent to the volcanic formations that abruptly delimit the dry southwest region from the more humid areas of Madagascar to the east.

Only two of the four long-established protected areas mentioned above harbour dry spiny forest and thicket fall within our study area (Tsimanampesotse National Park and Cap Sainte Marie Reserve). However five of the new protected areas established in 2015 (Gardner et al. 2018) contain dry spiny forest and thicket and lie largely within our study area. These include: (1) Mikea, between Morombe and the Manombo River, (2) Ranobe PK32, between the Manombo and Fiherenana Rivers, (3) Tsinjoriake, between the mouth of the Onilahy River and Toliara, and (4) Amoron-i Onilahy, along the lower Onilahy basin.

Today spiny thicket, deciduous forest and woodland form a highly fragmented patchwork in southwestern Madagascar, but they were formerly more abundant and had much stronger ecological connections across the region and to the much larger dry bioclimatic region to the north that encompasses most of the western half of Madagascar (Moat and Smith 2007, Vieilledent et al. 2018). The two dominant groups of the forest canopy today are tree Euphorbias, and members of the four genera of Didiereaceae occurring in Madagascar, (Alluaudia, Alluaudiopsis, Didierea, and Decarya) all of which are to a large degree endemic to this region. Vegetation cover is quite variable, with poorly studied correlations to soils, available nutrients in the soils, and substrate types (Moat and Smith 2007). Mills et al. (2012) suggest that woody plants in particular are sensitive to nutrient status of soils in arid and semiarid regions.

In his seminal treatment of the bioclimate of Madagascar, which recognized a total of 29 bioclimatic units mapped across the whole of Madagascar, Antoine Cornet distinguished a subarid (subaride) region in southwestern Madagascar (Cornet 1974). With only 350-650 $\mathrm{mm}$ mean annual precipitation, this region represents the driest of the five major bioclimatic 'levels' (étages) he recognized. Within the subarid region, cornet (1974) recognized three bioclimatic 'sub-levels' (sous-étages) based on increasing hydric deficit. The term 'subarid' (or sub-arid) is rarely used in English, as compared to 'semiarid', a term widely employed by the FAO and other UN agencies, and which has a similar meaning. A semiarid zone is formally defined as having an aridity index of 0.20-0.50 (i.e., annual precipitation divided by evapotranspiration, which is often denoted as P/ET) (Cornet 1974). These conditions prevail only in the driest part of Cornet's subarid region, the predominantly coastal area of $16,200 \mathrm{~km}^{2}$ that is the main subject of this article (Figure 1), and is dominated by southwestern dry spiny thicket (Moat and Smith, 2007).

For simplicity, we use the term 'semiarid' in the context of our study area, which serves to distinguish it from the remainder of Cornet's subarid region, and henceforth refer to it as the 'semiarid zone' (Table S1). The two larger, less arid and predominantly inland areas recognized by cornet in his subarid region do not have truly semiarid climates, and for these we retain the term subarid. We shall refer to the less arid, northernmost area as the 'upper subarid zone' and the southern area, which has a more gradual transition to the semiarid zone as the 'lower subarid zone (Figure 1) within Cornet's Étage Subaridé.

The semiarid zone consists of the sandy littoral strip along the southwestern coast and the lowest elevation portion of the limestone escarpment leading up to the Karimbola plateau. It stretches from the mouth of the Mangoky River, just north of the town of Morombe, located about $220 \mathrm{~km}$ north of Toliara, to Cap Sainte Marie (alias Cape Vohimena) at the southernmost tip of Madagascar. From there it extends east to the Manambovo River near the town of Tsiombe, then beyond to the mouth of the Ranofotsy River, just south of Andohahela National Park, $25 \mathrm{~km}$ west of Tôlagnaro (alias Fort Dauphin). That small area in the southeast constitutes an isolated rainshadow semi-desert with exceptionally high local endemism.

An important feature of the region is its erratic rainfall. Rainless periods can persist for as long as 12 months, during which a significant water deficit accumulates for most plants, and the entire annual precipitation is often concentrated in one or two short heavy rainstorms. The coastal strip is the driest portion of the region but it is a zone where the contribution of fog to total precipitation is significant, even during the generally dry months April to October (Donque 1975). Cornet (1974) had access to data from eight stations in the dry southwest when preparing his bioclimatic map; only three are situated within the semiarid zone. A more recent synthesis of data was provided by Oldeman (1990) (Table S2). Still, reliable long-term data on weather and climate are lacking.

Plant species diversity and endemism: Focusing on the diversity and endemism of vascular plant species of the semiarid zone, based on data extracted from the Madagascar Catalogue (2018), a total of 930 native vascular plant species in 107 plant families have been recorded, of which roughly $23 \%$ are endemic to the area. Summary data on the diversity of the better represented families is provided in Table 1.

Considering global tree diversity, a striking feature is the large number of taxonomic groups to which they belong including tree ferns, Gymnosperms and within the angiosperms-six families of monocots and 75 families of dicots (Thomas 2014). The range of

Table 1.Number of genera and species recorded in the semiarid zone of southwestern Madagascar for families with four or more tree species recorded in the zone, and number of species currently regarded as endemic to the zone following the taxonomic classification of The Angiosperm Phylogeny Group (2016)

\begin{tabular}{|c|c|c|c|}
\hline Family & Genera & Species & Endemic species \\
\hline Anacardiaceae & 4 & 9 & 5 \\
\hline Apocynaceae & 2 & 6 & 1 \\
\hline Asteraceae & 3 & 4 & 1 \\
\hline Bignoniaceae & 5 & 6 & 0 \\
\hline Boraginaceae & 3 & 11 & 2 \\
\hline Burseraceae & 1 & 19 & 7 \\
\hline Capparaceae & 5 & 8 & 2 \\
\hline Celastraceae & 7 & 8 & 3 \\
\hline Combretaceae & 1 & 8 & 3 \\
\hline Didiereaceae & 4 & 11 & 6 \\
\hline Ebenaceae & 1 & 7 & 0 \\
\hline Euphorbiaceae & 5 & 26 & 6 \\
\hline Fabaceae & 25 & 78 & 19 \\
\hline Malvaceae & 9 & 33 & 4 \\
\hline Meliaceae & 4 & 5 & 1 \\
\hline Moraceae & 2 & 10 & 1 \\
\hline Pedaliaceae & 1 & 5 & 1 \\
\hline Phyllanthaceae & 6 & 8 & 0 \\
\hline Rhamnaceae & 4 & 6 & 1 \\
\hline Rubiaceae & 9 & 10 & 0 \\
\hline Rutaceae & 5 & 7 & 2 \\
\hline Sapindaceae & 8 & 11 & 3 \\
\hline Sapotaceae & 2 & 4 & 0 \\
\hline Solanaceae & 1 & 4 & 2 \\
\hline Xanthorrhoeaceae & 1 & 5 & 2 \\
\hline
\end{tabular}


life forms and life history strategies among trees is also large, notably in dryland ecosystems where drought, nutrient status in soils, and unpredictable weather and climate provide strong selection pressure on desert trees and all other forms of organisms. This is particularly true in the drylands of southwest Madagascar.

Dryland trees: In our global database project, and for the dry southwest Malagasy tree flora considered here (Figure S1), we find it necessary to develop our own definition of dryland trees given that none of the numerous definitions presented used previously seems entirely satisfactory for our study areas. We use elements from the definitions offered by Shreve and Wiggins (1951), Bernhardt (2000), Felger et al. (2001), and Schatz $(2000,2001)$ to complement the following definition: In the context of drylands, trees are long-lived plants that develop at least one sturdy longlived trunk, from one to 20 meters or more in height. There may be additional vertical stems, but after cutting, burning, or browsing, it may be difficult or impossible to distinguish which stem was initially the main stem.

This definition includes longevity and the presence of a single, primary trunk, whether tall or short, as opposed to the multibranching life forms found in shrubs. Even in the absence of human impacts, many dryland trees-like some montane and arctic tundra trees-never attain five meters in height. Examples abound in the drylands of Africa and Madagascar, in genera such as Acacia, Adenium, Aloe, Commiphora, Cyphostemma, Euphorbia, and Moringa. Similarly, in many groups of Australian trees, lignotubers and other underground organs have evolved to allow trees to survive drought, fire, and severe grazing (Nicolle 2006).

To underscore the spectrum of life forms and taxonomic groups in which they occur, we use names such as 'monocot tree', 'dwarf tree', 'bottle tree', or 'arboreal cactus' when a dryland tree deviates from standard notions of trees. Dwarf trees, candelabra tree euphorbs, and monocot trees-those without lignified stems - can be recognized as special category of desert trees. In the evolutionary ecology of desert and dryland trees, succulence also merits special attention as it occurs in leaves and young stems, but also in tree trunks (and roots), producing a condition called pachycaul (alias bottle trees). In the dry southwest and other drylands, there are also many other adaptations to drought and unpredictability observed in trees (and other plants) such as ultra-rapid leaf shedding during drought, and thorns or spines.

In preparing the distribution maps presented in this article, we followed Cornet (1974) and Schatz (2000) for bioclimatic regions, and for vegetation cover and protected areas, we followed Moat and Smith (2007), and supplemented their maps by other recent unpublished data. For species distribution, we used the Tropicos $₫$ database. Regarding taxonomy, we followed the on-going Catalogue of Vascular Plants of Madagascar project (http://www.tropicos.org/project/mada) and APG IV (The Angiosperm Phylogeny Group 2016).

DATA SAMPLING AND ANALYSIS. The second lead-author has conducted numerous field trips in southwest Madagascar over the past 28 years. Shorter trips devoted to this study have been undertaken by the first and third authors since 2002. Field observations of the information used to complete the various fields in the database for the trees included were supplemented by consultation of the Catalogue of the Plants of Madagascar database (Madagascar Catalogue (MadCat) 2018), literature searches, and careful review of herbarium specimens of the taxa considered for the MadCat database, in the herbaria at the National Museum of Natural History in Paris, France, and at the National Herbarium at Tzimbazaza, Antananarivo, Madagascar, as well as the Royal Botanic Gardens Kew, UK, and Missouri Botanical Garden, USA

Included in DTsMada are data regarding species distribution, bioclimate, habitat categories and endemicity derived from the Madagascar Catalogue (2018). Additionally, we note endemicity to the semiarid zone, based on MadCat, and our study of herbarium specimens and field observations. We also note presence or absence of a series of eco-physiological features thought to be of functional and adaptive significance, based on herbarium specimens and our own field observations. These include: the pachycaul (swollen trunk) life form (e.g., Adansonia), stem succulence (e.g., Didiereaceae), leaf succulence (e.g., Aloe), and the presence of spines or thorns. Further, we note the presence of unusual bark characteristics such as peeling (e.g., most Commiphora), and leaf duration (deciduous, evergreen or semi-deciduous). Data for conservation risk assessments for some taxa have been obtained from the IUCN Red List of Threatened Species (IUCN 2015) and the Red List published by the IUCN Madagascar Plant Specialist Group (2011) (Table 2). Assessments published in 1998 used earlier criteria that are no longer regarded as valid (e.g., examples of criteria $1,2,3)$, with some of the assessments still being provisional, i.e., having not yet been validated by the IUCN Red List authority. Additional adaptive traits recorded in the DTsMada database include sexual system (hermaphrodite, monoecious or dioecious), long distance dispersal syndromes, e.g., anemochory, the ability to coppice, the type of habitat(s) where the species is most commonly found, and height range (m) at maturity.

\section{RESULTS AND DISCUSSION}

The semiarid zone harbors 355 documented tree species in 156 genera and 55 families in a total area of approximately $16,200 \mathrm{~km}^{2}$. Endemism is also high: a total of 316 (89.0\%) of the tree species recorded from this zone are endemic to Madagascar, and 76 species $(21.4 \%$ of the tree flora) are restricted to the zone, and a further 111 are confined to the dry southwest. Therefore, based on our results, 187 (52.7\%) of the 355 tree species identified in our study area are regional endemics. Furthermore, two genera $(1.2 \%)$ are strictly endemic to the semiarid zone (Alluaudiopsis and Salvadoropsis), a total of 12 genera (7.7\%) are endemic to the dry southwest, and 38 genera (24.4\%) of the 156 present are endemic to Madagascar (Table 3). More than half (52.7\%) of the tree flora in the broader subarid region as a whole (sensu cornet 1974) is endemic to that region and more than a fifth is endemic to the semiarid zone.

In order to illustrate some of the biogeographical patterns and life history traits that occur in the arboreal flora of the semi-

Table 2. IUCN risk of extinction assessment categories for 117 evaluated Malagasy endemic tree species of the dry southwest region of Madagascar. (Sources: IUCN website www.iucnredlist.org; IUCN Madagascar Plant Specialist Group (MPSG) 2011. CR: Critically Endangered; EN: Endangered; VU: Vulnerable; NT: Near Threatened; LC: Least Concern)

\begin{tabular}{llcccccc} 
Source & Year published & CR & EN & VU & NT & LC & Total \\
\hline IUCN & 1998 & 1 & 3 & 4 & 1 & 1 & 10 \\
IUCN & 2004 & & 2 & 2 & & 7 & 11 \\
GSPM & 2011 & 5 & 26 & 21 & 16 & 18 & 86 \\
IUCN & 2012 & & 1 & & & 2 & 3 \\
IUCN & 2014 & & 2 & 1 & 1 & 3 & 7 \\
\hline & Totals & 6 & 34 & 28 & 18 & 31 & 117
\end{tabular}


Table 3. Summary of the data available from the Madagascar Catalogue for the 355 known species of trees of the semiarid zone of southwestern Madagascar. (Data include three levels of endemism: endemic to (i) Madagascar as a whole, (ii) to the dry southwest region, and (iii) to the coastal semiarid zone. Data for selected morphological traits are also shown indicating correlation of each to degrees of endemism. Note that nearly $30 \%$ of assessed species were considered to be Endangered (EN), and $58.1 \%$ as Vulnerable or higher risk, including a significant portion that are Endangered or Critically Endangered)

\begin{tabular}{llll} 
& Madagascar & dry southwest & semiarid zone \\
\hline endemic species & 316 & 187 & 76 \\
non-endemic species & 39 & 168 & 279 \\
Percent endemism & $89.0 \%$ & $52.7 \%$ & $21.4 \%$ \\
Number of pachycauls & 26 & 17 & 10 \\
Percent of endemic flora & $8.3 \%$ & $9.1 \%$ & $13.2 \%$ \\
Number of leaf succulents & 17 & 15 & 9 \\
Percent of endemic flora & $5.4 \%$ & $8.0 \%$ & $11.8 \%$ \\
Number of armed species* & 45 & 32 & 15 \\
Percent of endemic flora & $14.2 \%$ & $17.1 \%$ & $19.7 \%$
\end{tabular}

arid zone, we now present four case studies of three genera with many endemic species, each in a different, widespread tropical family, and the four Malagasy genera of Didiereaceae.

CASE STUDY 1. The genus Adansonia (Malvaceae): Adansonia comprises eight species, of which six are endemic to Madagascar (Cron et al. 2016). Like Pachypodium, this iconic group shows a clear distribution pattern in various dry areas of sub-Saharan Africa and Madagascar, but with a single species, A. gregorii F. Muell., endemic to the Kimberley ranges in northwestern Australia (Baum 1995, Baum et al. 1998, Leong Pock Tsy et al. 2009). As discussed by Raveloson et al. (2014), Baobabs are comparable to lemurs in their iconic value and the importance of strengthening educational and conservation measures for their protection and integration in far-seeking programs of conservation and sustainable development. To this call to action, we would add a third component, namely ecological restoration.

Adansonia za is widespread throughout the subarid and dry bioclimatic regions of Madagascar. $A$. grandidieri occurs mostly in the central-west part of the country (around Morondava), but just extends into the semiarid zone. A. rubrostipa is coastal in distribution and is certainly the best represented species within the semiarid zone (Figure 3). The other three Malagasy species, A. suarezensis, A. perrieri, and A. madagascariensis, are concentrated in the north and northwest, and do not occur in the dry southwest. It seems that $A$. digitata, the most widespread Baobab having a vast range in Africa, was intentionally introduced to Madagascar from sub-Saharan Africa where it is native, and is cultivated, never wild, in Madagascar, India, and Australia (Baum 1995, Pettigrew et al. 2012). However, in southern Oman and Yemen it appears to have been introduced more than 1000 years ago, and now occurs as an escape from cultivations in a few localities (Aronson et al. 2017).

In Madagascar as in Africa, Adansonia digitata shows polyploidy and its distribution is linked to villages, both active and abandoned (Leong Pock Tsy et al. 2009). Adansonia species in general tend to be left uncut by people clearing areas for agriculture because their wood is of little use for construction, firewood, or charcoal, and because the trunks are a valuable source of moisture for livestock in periods of prolonged drought when stems can be cut and fed to animals. The tree has many other domestic uses as well, including fiber from the bark used for various purposes. Furthermore, there are strong ritual or spiritual uses and connotations associated with this widespread, iconic group of

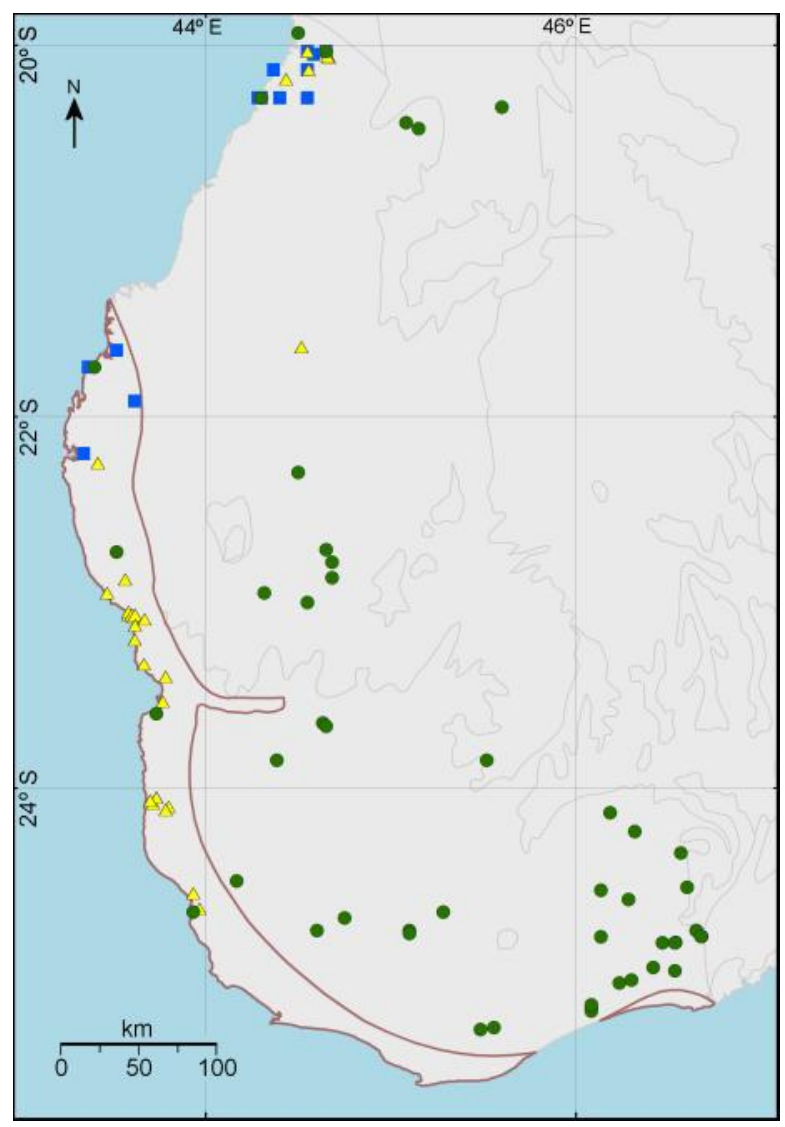

Figure 3. Known occurrence in the Dry Southwest Region of the three endemic species of Adansonia - A. grandidieri (blue squares), A. rubrostipa (yellow triangles), and $A$. za (green dots) that enter the Semiarid Zone (purple outline).

bottle trees (Leong Pock Tsy et al. 2009). As a result the trees are exposed to human-mediated evolutionary pressures and opportunities that may result in the patterns of hybridization brought to light by Leong Pock Tsy et al. (2013).

CASE STUDY 2. The genus Pachypodium (Apocynaceae): The 25 species of the pachycaulous genus Pachypodium, like those of Adansonia, are mostly concentrated in Madagascar. According to Rapanarivo and Leeuwenberg (1999), no less than 20 species are endemic to Madagascar while five occur in Angola, Mozambique, South Africa, Swaziland, and Zimbabwe. The genus shows an extraordinary amplitude of life forms and habitats, ranging from nearly prostrate shrubs in granitic hills of central Madagascar to succulent trees 4-6 m tall in the canyons of the Gariep river ( $P$. namaquanum), near the South African border with Namibia. In Madagascar, five species enter the semiarid zone (Figure 4). These include four trees- $P$. geayi, P. lamerei, P. meridionale, and $P$. mikea, and also the shrubby species, $P$. cactipes.

Three of the four arborescent species of Pachypodium in Madagascar occur in the semiarid zone yet extend into the subarid region as a whole, while a single species, only recently discovered, is endemic to the coastal areas of the zone between Toliara and Morombe, where it is partially sympatric with the other tree species (Lüthy 2005). The well-known dwarf species P. brevicaule is endemic to quarzite outcroppings in central Madagascar and does not occur in the dry southwest. Pachypodium brevicaule and other species are much sought after as ornamentals for the horticultural trade, which has led to over-harvesting and reduction of its range. The natural populations of certain species have also 


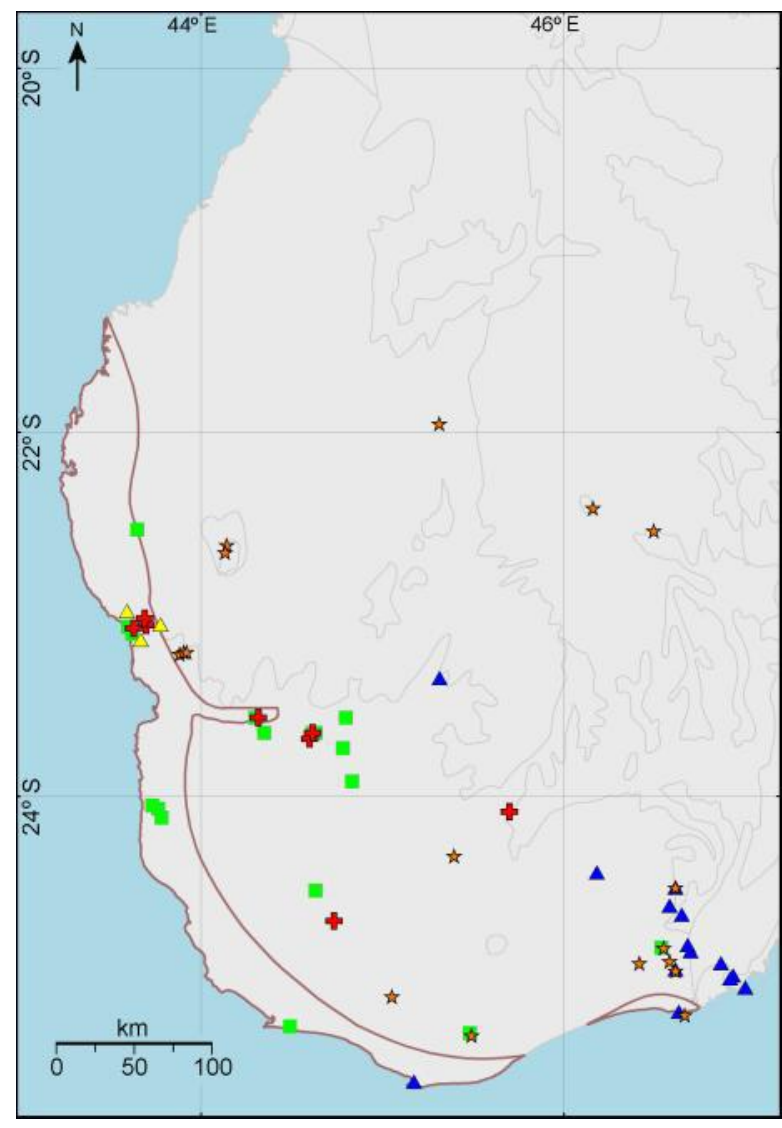

Figure 4. Pachypodium: of the 20 species in Madagascar, only five enter the Semiarid Zone: four are trees - P. geayi (green squares), P. lamerei (gold stars), P. mikea (yellow triangles), and P. meridionale (red crosses), and one a shrub, $P$. cactipes (blue triangles), only P. mikea, a narrow endemic, is strictly restricted there.

been modified due to translocation within Madagascar and illegal commerce overseas (Sajeva et al. 2007). All Malagasy species of the genus are listed in CITES (Convention on International Trade in Endangered Species of Wild Fauna and Flora)-three in Appendix I, and all others in Appendix II (Sajeva et al. 2007).

CASE STUDY 3. the four Malagasy genera of Didiereaceae: We consider the Didiereaceae, which are similar in appearance to various primitive cacti and are grouped with them in the order Caryophyllales (The Angiosperm Phylogeny Group 2016). In Madagascar, there are 11 species in four genera-Alluaudia, Alluaudiopsis, Decarya, and Didierea. Until recently, this family was considered to be endemic to Madagascar, however based on molecular studies (The Angiosperm Phylogeny Group 2016), it now also includes 11 African species in three genera formerly placed in Portulacaceae-Ceraria (six species), Calyptrotheca (two species), and Portulacaria (three species). Notably, all these African taxa are mainly shrubs-or rarely small trees-many with broad distributions. In contrast, most of the 11 taxa in Madagascar are unequivocally trees, all are endemic to the island and all occur within the semiarid zone, to which five species are endemic. In fact, only two species, Alluaudia humbertii and A. dumosa, occur beyond the subarid region, having outlying populations in the center-south of the country near the town of Ihosy (Figure 5). Among the four Malagasy genera, Alluaudiopsis appears to be the most ancient (Applequist and Wallace 2000) and, as in Adansonia, various episodes of polyploidization within the genus seem to have occurred.

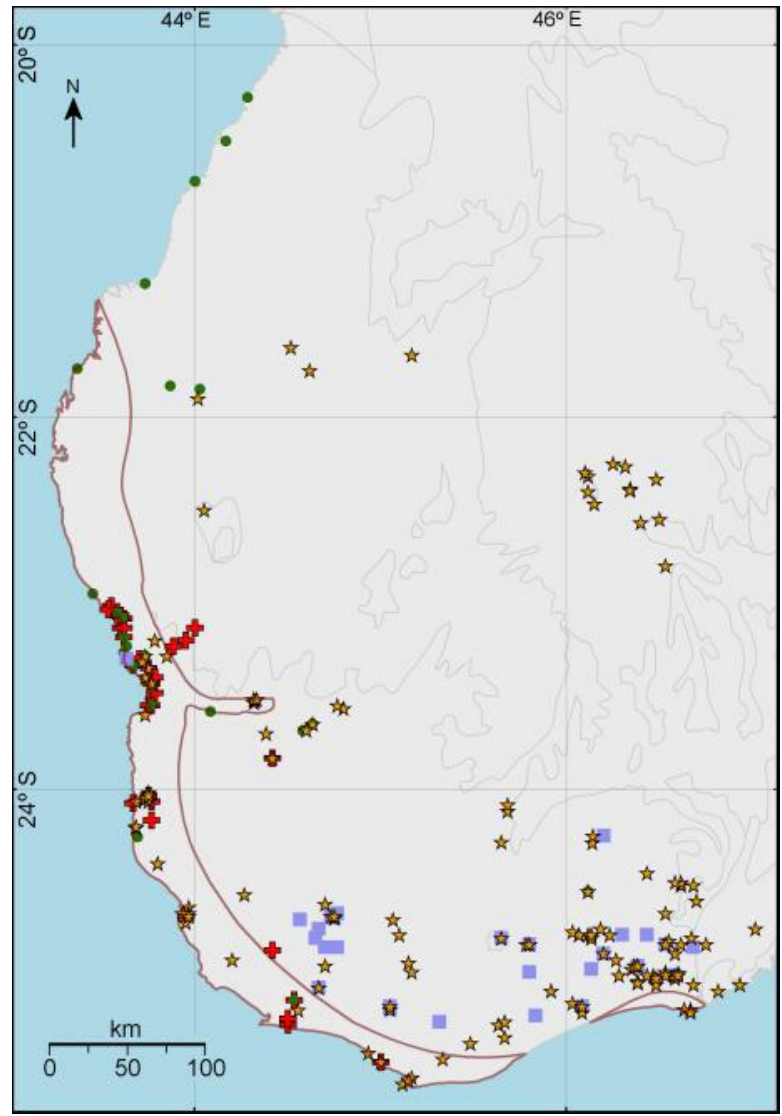

Figure 5. Distribution of Didiereaceae in Madagascar, comprising 11 species in 4 genera: 6 species of Alluaudia (gold stars); 2 species of Alluaudiopsis (red crosses); 1 species of Decaryia (blue squares); 2 species of Didierea (green dots).

Like the well-known Spekboom of southern Africa (Portulacaria afra), many Malagasy Didiereaceae can be reproduced from cuttings or, for those species where it is possible, stancheons (i.e., very large cuttings, typically $50-200 \mathrm{~cm}$ long). These rooted cuttings can grow quickly and serve as dense living fences (Figure S2). This is true especially for Didierea madagascariensis and Alluaudia procera. Additionally, Alluaudia ascendens produces relatively sturdy wood that is cut into wide, thin boards used as sheathing to cover exterior walls of houses (Schatz 2000). It is possible that the distribution of some or all of these trees was modified and extended by intentional use and transport by people. Moreover, the thick stems of several species are used for firewood, and young leaves of some species are highly palatable to livestock. Didierea madagascariensis is a fast-growing, pioneer colonizer of sandy habitats that could be of particular value in ecological restoration and rehabilitation.

CASE STUDY 4. Baudouinia (Fabaceae): This is a hardwood tree that once was more abundant. Baudouinia rouxevillei $\mathrm{H}$. Perrier, a small to medium-sized tree, with wood that is highly prized by wood-workers. It is restricted to a small area of the Mahafaly Plateau between the Fiherenana River in the north and the Itambono corridor southwest of Betioky, where it occurs in low, deciduous woodland and scrubland on limestone 100-300 m above sea level. Historically, it was an offence to cut the wood, as it was reserved for the King; the translation of the local name-Manjakabetany_means 'King's wood' or 'King of the Earth' (Du Puy 2002). Yet that taboo was insufficient. Already in 
2002, it was considered "rare and endangered due to its restricted distribution and over-collection for its ornamental wood" (Du Puy 2002: 71). We wonder if that combination of factors might not be a feature relevant for many tree species in the region, in this small genus and many others. Attention has recently been drawn by Ranaivoson et al. (2015) to a worrisome situation regarding Tamarindus indica, another multi-purpose legume tree of the southwest semiarid region that for centuries, according to these authors, was a sacred tree among the local Mahafaly people, strictly protected from cutting by taboos (fady). However, in recent years people started to disregard the taboos, and cut down the trees for firewood, to the point where the species is now disappearing.

The shifting baseline syndrome (cf. Pauly 1995) and artificial negative selection forces in direct relation to shrinking stocks and loss of functional biodiversity also exists with regard to trees and other useful plants in arid and semiarid areas in general. It is suggested that hardwood trees in the genera Albizia, Dalbergia, Diospyros, Operculicarya, and Baudouinia are especially at risk. Thus, species of special concern include Albizia aurisparsa (Drake) R. Vig., A. mahalao Capuron, Dalbergia xerophila Bosser \& Rabevohitra, Dichrostachys venosa Villiers, and Diospyros sakalavarum $\mathrm{H}$. Perrier. Further research on preferences and uses of trees by local people in the dry southwest of Madagascar would no doubt be of great value, such as the study performed recently in the Analalava area, near Foulpointe, eastern Madagascar by Lavialle et al. (2015).

\section{CONCLUSIONS}

In a surprising number of Earth's vast drylands, highly diverse arboreal floras still occur and provide the infrastructure for multilayered woodlands and shrublands such as those of the dry southwest of Madagascar. These provide multiple services to people and other forms of life (Le Floc'h and Aronson 2013). We argue that the social-ecological and economic roles of these tree (and shrub) species must be re-evaluated. To rectify this situation, reliable up-to-date data are needed to enable us to understand biodiversity and biogeographical patterns and interdependence between the taxa present, and the ecosystem functions in different habitats. On-line, interactive databases are thus invaluable tools to provide a summary of current knowledge and knowledge gaps facilitating targeted research to improve the knowledge base.

Our primary goal here has been to contribute to the knowledge base necessary for developing and implementing coordinated, science-based, and far-sighted conservation, planning, management, and restoration programs in drylands worldwide, seeking to strengthen sustainable local economic development and human wellbeing, combat desertification and ecosystem degradation and initiate restorative processes at ecosystem, landscape, and bioregional levels. The importance of native dryland trees and the assemblages they form-or once formed in areas where there has been environmental degradation-has been underestimated and under-studied, or else forgotten since most trees were removed long ago. We also note that at the national scale in Madagascar, many new priority conservation areas have been proposed or are already in different stages of formal recognition. Obviously, it will take time for effective management of the new protected areas to be established, and for on-site protection and management to become truly effective. We hope that this contribution and the database we have assembled will be of use.

\section{ACKNOWLEDGEMENTS}

We warmly thank Thibaud Aronson for his valiant help with the manuscript and data base and Rajaonary Andriaharimananjaka Fanomezantsoa for his timely help with figures. We warmly thank all of the remarkable team of Missouri Botanical Garden Madagascar. We are also grateful to the editors, Pete Lowry, and two anonymous reviewers for their lucid comments on previous versions of the manuscript.

\section{REFERENCES}

Applequist, W. L. and Wallace, R. S. 2000. Phylogeny of the Madagascan endemic family Didiereaceae. Plant Systematics and Evolution 221, 3-4: 157-166. <https://doi.org/10.1007/BF01089291>

Aronson, J., Vallauri, D., Jaffré, T. and Lowry II, P. P. 2005. Restoring dry tropical forests. In: Forest Restoration in Landscapes: Beyond Planting Trees. S. Mansourian, D. Vallauri, and N. Dudley (eds.), pp 285-290. Springer, New York.

Aronson, J., Aronson, T. B., Patzelt, A., Knees, S. G., Lewis, G. P., et al. 2017. Paleorelicts or archaeophytes: Enigmatic trees in the Middle East. Journal of Arid Environments 137: 69-82. <https://doi.org/10.1016/j.jaridenv.2016.11.001>

Baum, D. A. 1995. A Systematic Revision of Adansonia (Bombacaceae). Annals of the Missouri Botanical Garden 82, 3: 440-471. <https://doi.org/10.2307/2399893>

Baum, D. A., Small, R. L. and Wendel, J. F. 1998. Biogeography and floral evolution of baobabs (Adansonia, Bombacaceae) as inferred from multiple data sets. Systematic Biology 47, 2: 181-207. <https://doi.org/10.1080/106351598260879>

Bernhardt, P. 2000. Convergent evolution and adaptive radiation of beetle-pollinated angiosperms. In: Pollen and Pollination. A. Dafni, M. Hesse and E, Pacini (eds.), pp 293-320.Springer, Vienna.

Birkinshaw, C., Lowry II, P. P., Raharimampionona, J. and Aronson, J. 2013. Supporting Target 4 of the Global Strategy for Plant Conservation by integrating ecological restoration into the Missouri Botanical Garden's Conservation Program in Madagascar. Annals of the Missouri Botanical Garden 99, 2: 139-146. <https://doi.org/10.3417/2012002>

Bond, W. J. and Silander, J. A. 2007. Springs and wire plants: anachronistic defences against Madagascar's extinct elephant birds. Proceedings of the Royal Society of B: Biological Sciences 274, 1621: 1985-1992. $<$ https://doi.org/10.1098/rspb.2007.0414>

Burkhart, A. 1976. A monograph of the genus Prosopis (Leguminosae subfam. Mimosoideae) Part I. Journal of the Arnold Arboretum 57, 4: 450-525.

Callmander, W., Phillipson, P. B., Schatz, G. E., Andriambololonera, S., Rabarimanarivo, M., et al. 2011. The endemic and non-endemic vascular flora of Madagascar updated. Plant Ecology and Evolution 144, 2: 121-125. <https://doi.org/10.5091/plecevo.2011.513>

Castillo, J. P., Verdu, M. and Valiente-Banuet, A. 2010. Neighborhood phylodiversity affects plant performance. Ecology 91, 12: 3656-3663. $<$ https://doi.org/10.1890/10-0720.1>

Cornet, A. 1974. Essai de Cartographie Bioclimatique à Madagascar Vol. 55. ORSTOM, Paris. Available at <http://www.documentation.ird.fr/hor/fdi:06946>

Cron, G. V., Karimi, N., Glennon, K. L., Udeh, C., Witkowski, E. T. F., et al. 2016. One African baobab species or two? A re-evaluation of Adansonia kilima. South African Journal of Botany 103: 312. $<$ https://doi.org/10.1016/j.sajb.2016.02.036>

Crowley, B. E. and Godfrey, L. R. 2013. Why all those spines? Anachronistic defences in the Didiereoideae against now extinct lemurs. South African Journal of Science 109, 1-2: 1-7. <https://doi.org/10.1590/sajs.2013/1346>

Dewar, R. E. and Richard, A. F. 2007. Evolution in the hypervariable environment of Madagascar. Proceedings of the National Academy of Sciences of the United States of America 104, 34: 13723-13727. <https://doi.org/10.1073/pnas.0704346104>

Donque, G. 1975. Contribution à l'Étude Géographique du Climat de Madagascar. Nouvelle Imprimerie des Arts Graphiques à Tananarive, Tananarive. 
Du Puy, D. J. 2002. The Leguminosae of Madagascar. Royal Botanic Gardens, Kew.

Du Puy, D. J. and Moat, J. 1996. A refined classification of the primary vegetation of Madagascar on the underlying geology: Using GIS to map its distribution and to assess its conservation status. In: Biogéographie de Madagascar. W. R. Lourenço (ed.), pp 205-218. ORSTOM, Paris.

Felger, R. S., Johnson, M. B. and Wilson, M. F. 2001. The Trees of Sonora, Mexico. Oxford University Press, New York.

Gardner, C. J., Nicoll, M. E., Birkinshaw, C., Harris, A., Lewis, R. E., et al. 2018. The rapid expansion of Madagascar's protected area system. Biological Conservation 220: 29-36. <https://doi.org/10.1016/j.biocon.2018.02.011>

Gautier, L., Chatelain, C., Callmander, M. W. and Phillipson, P. B. 2012. Richness, similarity and specificity of Madagascar flora compared with Sub-Saharan Africa. Plant Ecology and Evolution 145, 1: 55-64. <https://doi.org/10.5091/plecevo.2012.591>

Grubb, P. J. 2003. Interpreting some outstanding features of the flora and vegetation of Madagascar. Perspectives in Plant Ecology, Evolution and Systematics 6, 1-2: 125-146. <https://doi.org/10.1078/1433-8319-00046>

IUCN Madagascar Plant Specialist Group. 2011. Liste Rouge des Plantes Vasculaires endémiques de Madagascar. Groupe des Spécialistes des Plantes de Madagascar (IUCN/SSC Madagascar Plant Specialist Group). Antananarivo, Madagascar.

Harper, G. J., Steininger, M. K., Tucker, C. J., Juhn, D. and Hawkins, F. 2007. Fifty years of deforestation and forest fragmentation in Madagascar. Environmental Conservation 34, 4: 325-333. <https://doi.org/10.1017/S0376892907004262>

IUCN. 2015. The IUCN Red List of Threatened Species. <http://www.iucnredlist.org> accessed 30 June 2015.

Lal, R., Safriel, U. and Boer, B. 2012. Zero net land degradation: A new sustainable development goal for Rio+ 20. In: United Nations Convention to Combat Desertification (UNCCD).

Lavialle, J., Carrière, S. M., Miandrimanana, C., Tilahimena, A., Birkinshaw, C. R. and Aronson, J. 2015. Complementarity of native and introduced tree species: exploring timber supply on the east coast of Madagascar. Madagascar Conservation \& Development 10, s3: 137-143 <https://doi.org/10.4314/mcd.v10i3.6>

Le Floc'h, E. \& Aronson, J. 2013. Les arbres des déserts. Enjeux et promesses. Actes Sud, Arles.

Leong Pock Tsy, J.-M., Lumaret, R., Mayne, D., Vall, A. O. M., Abutaba, Y. I. M., Sagna, M., Rakotondralambo Raoseta, S. O. and Danthu, P. 2009. Chloroplast DNA phylogeography suggests a West African centre of origin for the baobab, Adansonia digitata L. (Bombacoideae, Malvaceae). Molecular Ecology 18, 8: 1707-1715. <https://doi.org/10.1111/j.1365-294X.2009.04144.X>

Leong Pock Tsy, J.-M., Lumaret, R., Flaven-Noguier, E., Sauve, M., Dubois, M.-P. and Danthu, P. 2013. Nuclear microsatellite variation in Malagasy baobabs (Adansonia, Bombacoideae, Malvaceae) reveals past hybridization and introgression. Annals of Botany 112, 9: 1759-1773. <https://doi.org/10.1093/aob/mct230>)

Lowry II, P. P., Schatz, G. E. and Phillipson, P. B. 1997. The classification of natural and anthropogenic vegetation in Madagascar. In: Natural Change and Human Impact in Madagascar. S. M. Goodman and B. D. Patterson (eds.), pp 93-123, Smithsonian Institution Press, Washington and London.

Lüthy, J. 2005. Pachypodium mikea a new arborescent species from Madagascar. Cactus and Succulent Journal 77, 4: 178-186. <https://doi.org/10.2985/0007-9367(2005)77[178:PMANAS]2.0.CO;2>

Madagascar Catalogue (MadCat). 2018. Catalogue of the Vascular plants of Madagascar. Missouri Botanical Garden, Saint-Louis. Available at $<$ http://www.efloras.org/madagascar>.

Mills, A. J., Milewski, A. V., Fey, M. V., Gröngröft, A., Petersen, A. and Sirami, C. 2012. Constraint on woody cover in relation to nutrient content of soils in western southern Africa. Oikos 122, 1: 136-148. <https://doi.org/10.1111/j.1600-0706.2012.20417.x>

Moat, J. and Smith, P. 2007. Atlas of the Vegetation of Madagascar. Royal Botanic Gardens Kew, Richmond, UK.

Nicolle, D. 2006. A classification and census of regenerative strategies in the eucalypts (Angophora, Corymbia and Eucalyptus-Myrtaceae), with special reference to the obligate seeders. Australian Journal of Botany 54,4 : 391-407. <https://doi.org/10.1071/BT05061>
Oldeman, L. R. 1990. Technical report on agroclimatic characterization of Madagascar. Technical Paper 21. International Soil Reference Information Center, Netherlands.

Pauly, D. 1995. Anecdotes and the shifting baseline syndrome of fisheries. Trends in Ecology \& Evolution 10, 10: 430. <https://doi.org/10.1016/S0169-5347(00)89171-5>

Pettigrew, F. R. S., Jack, D. Bell, K. L., Bhagwandin, A., Grinan, E., et al. 2012. Morphology, ploidy and molecular phylogenetics reveal a new diploid species from Africa in the baobab genus Adansonia (Malvaceae: Bombacoideae). Taxon 61, 6: 1240-1250.

Phillipson. P. B. 1994. Madagascar. In: Centres of Plant Diversity: A Guide and Strategy for their Conservation, Europe, Africa, South West Asia and the Middle East. S. D. Davis, V. H. Heywood and A. C. Hamilton (eds.), pp 271-281. World Wide Fund for Nature (WWF) and ICUN - World Conservation Union, Cambridge, U.K.

Phillipson. P. B. 1996. Endemism and non-endemism in the flora of south-west Madagascar. In: Biogéographie de Madagascar. W. R. Lourenço (ed.), pp 125-136, ORSTOM, Paris.

Phillipson. P. B. 2006. A Catalogue of the Vascular Plants of Madagascar. In: Taxonomy and Ecology of African Plants, their Conservation and Sustainable Use. S. A. Ghazanfar and H. Beentje (eds.), pp 613-627, Royal Botanic Gardens, Kew.

Rabarimanarivo, M., Andriambololonera, S., Callmander, M.W., Lowry II, P. P., Phillipson, P. B. 2014. Madagascar Catalogue: Progress Report and New Insights. 20th Congress of AETFAT, Stellenbosch, South Africa. January 13-17, 2014.

Ranaivoson, T., Brinkmann, K., Rakouth, B. and Buerkert, A. 2015. Distribution, biomass and local importance of tamarind trees in south-western Madagascar. Global Ecology and Conservation 4: 14-25. <https://doi.org/10.1016/j.gecco.2015.05.004>

Randriamalala, J. R., Radosy, H. O., Razanaka, S., Randriambanona, H. and Hervé, D. 2016. Effects of goat grazing and woody charcoal production on xerophytic thickets of southwestern Madagascar. Journal of Arid Environments 128: 65-72. <https://doi.org/10.1016/j.jaridenv.2016.01.002>

Rapanarivo, S. H. J. V. and Leeuwenberg, A. J. M. 1999. Taxonomic revision of Pachypodium. Series of revisions of Apocynaceae: 48. In: Pachypodium (Apocynaceae): taxonomy, habitats and cultvation. S. H. J. V. Rapanarivo, J. J. Lavranos, A. J. M. Leeuwenberg and W. Roosli (eds.), pp 1-82. Balkema, Rotterdam.

Raveloson, C. O., Andriafidison, D., Razafimanahaka, J. H., Rabesihanaka, S. and Jenkins, R. K. B. 2014. Les baobabs de Madagascar : quel cadre réglementaire pour leur conservation ? Madagascar Conservation \& Development 9, 1: 31-35.

Reed, M. S. and Stringer, L. C. 2016. Land Degradation, Desertification and Climate Change. Routledge, New York.

Reynolds, J. F., Smith, D. M. S., Lambin, E. F., Turner, B., Mortimore, M., et al. 2007. Global desertification: building a science for dryland development. Science 316, 5826: 847-851. <https://doi.org/10.1126/science.1131634>

Roelens, J.-B., Vallauri, D., Razafimahatratra, A., Rambeloarisoa, G. and Razafy, F. L. 2010. Restauration des paysages forestiers. Cinq ans de réalisations à Fandriana-Marolambo (Madagascar). Unpubl. report WWF p. 92.

Sajeva, M., Carimi, F. and McGough, N. 2007. The Convention on International Trade in Endangered Species of Wild Fauna and Flora (CITES) and its Role in Conservation of Cacti and Other Succulent Plants. Functional Ecosystems and Communities 1, 2: 80-85.

SAPM. 2018. Système des Aires Protégées de Madagascar. [WWW Document]. $<$ http://www.rebioma.net/index.php/fr/2014-05-30-08-40-13/2014-05-3008-51-51> accessed 18 April 2018.

Schatz, G. E. 2000. Endemism in the Malagasy tree flora. In: Diversité et Endémisme à Madagascar, Colloque International Biogéographie de Madagascar. S. M. Goodman and W. R. Lourenço (eds.), pp 1-9. Muséum d'Histoire Naturelle, Paris.

Schatz, G. E. 2001. Generic tree flora of Madagascar. Royal Botanic Gardens, Kew and Missouri Botanical Garden, USA.

Shreve, F. and Wiggins, I. L. 1951. Vegetation and flora of the Sonoran Desert. Carnegie Inst. of Wash., Washington, DC. p. 192. 
Sunderland, T. C. H., Apgaua, D., Baldauf, C., Blackie, R., Colfer, C., et al. 2015. Global dry forests: a prologue. International Forestry Review 17, S2. <https://doi.org/10.1505/146554815815834813>

The Angiosperm Phylogeny Group. 2016. An update of The Angiosperm Phylogeny Group classification for the orders and families of flowering plants: APG IV. Botanical Journal of the Linnean Society 181, 1: 1-20. <https://doi.org/10.1111/boj.12385>

Thomas, P. A. 2014. Trees: Their Natural History. Cambridge University Press, Cambridge.

Verdu, M., Rey, P. J., Alcantara, J. M., Siles, G. and Valiente-Banuet, A. 2009. Phylogenetic signatures of facilitation and competition in successional communities. Journal of Ecology 97, 6: 1171-1180. <https://doi.org/10.1111/j.1365-2745.2009.01565.x>

Vieilledent, G., Grinand, C., Rakotomalala, F. A., Ranaivosoa, R., Rakotoarijaona, J.R., et al. 2018. Combining global tree cover loss data with historical national forest-cover maps to look at six decades of deforestation and forest fragmentation in Madagascar. Biological Conservation 222: 189-197. <https://doi.org/10.1016/j.biocon.2018.04.008>

Virah-Sawmy, M., Gardner, C. J. and Ratsifandrihamanana, A. N. 2014. The Durban Vision in practice: Experiences in the participatory governance of Madagascar's new protected areas. In: Conservation and Environmental Management in Madagascar. I. R. Scales (ed.), pp 216-251. Routledge, London.

Waeber, P. O., Wilmé, L., Ramamonjisoa, B., Garcia, C., Rakotomalala, D. et al. 2015. Dry forests in Madagascar, neglected and under pressure. International Forestry Review 17, (S2): 127-148. <https://doi.org/10.1505/146554815815834822>

\section{SUPPLEMENTARY MATERIAL}

Available online only

Figure S1. Spiny forest-thicket in the Dry Southwest region of Madagascar.

Figure S2. Use of Semiarid Zone trees by local communities.

Figure S3. Exemplary taxa and morphological adaptations.

Table S1. Summary of names used by Cornet (1974), Schatz (2000) and the present authors for each biogeographic area.

Table S2. Climatic data for the driest stations of the coastal zone of the Dry Southwest region of Madagascar.

Table S3. Ecogeographical database for the dry southwest Malagasy tree flora. 